\title{
Viewpoint: Selecting the 5 most important papers in the first 50 years of the Journal of Range Management
}

\author{
MITCHEL P. McCLARAN
}

Author is associate professor of range management, School of Renewable Natural Resources, 325 Biological Sciences East, University of Arizona, Tucson, Ariz. 85721

\section{Abstract}

A graduate seminar to select the 5 most important papers published in the first 50 years of the Journal of Range Management $(J R M), 1948-1997$, cultivated an appreciation for the development of the discipline of rangeland science and management, and provided some historical perspective to judge the JRM. A review of textbooks, and papers describing early milestones and the use of citation counting were helpful in developing criteria to discriminate the importance of papers. The greatest disagreement among the 9 participants focused on the use of citation counts as a criterion: 2 students used only counts and 3 students refused to use counts. Eighteen papers received at least 1 vote as a top 5 paper, and 2 plant succession-vegetation monitoring papers were clearly the most popular. The exercise revealed that discontent with the $J R M$ is not new. Although the $J R M$ now covers a wider variety of topics, including both reductionist and synthetic works, some students felt that it was less encompassing of multiple values of rangelands and the breadth of rangeland science than recent texts. The students found that the selection of important papers expanded their understanding of the discipline and their resolve to publish in the JRM. Ideally, others will be challenged to perform this review for the benefit of students, the discipline, and the JRM.

Key Words: education, disciplinary history, citation counting

The proximate goal of a graduate seminar at the University of Arizona in the spring semester of 1998 was to select the 5 most important papers published in the first 50 years (1948-1997) of the Journal of Range Management (JRM). The ultimate goal was to cultivate an understanding and appreciation for the development of the discipline of rangeland science and management. The 50 continuous years of publication was a very efficient vehicle to move the students through the history of the discipline, while the selection of the 5 most important papers gave focus to the journey. This experience was especially valuable for the graduate students with degrees in other disciplines, and for all partici-

Acknowledgments: This paper is dedicated to the students who participated in this course: Carlos Alaca-Galvan, Deborah Angell, Sharon Biedenbender, Julie Conely, Paulette Ford, Barry Imler, Wilma Renken, Carolyn Watson, and Dave Womack. I thank S. Clark Martin for attending most of our class sessions, and helping us understand the context of developments and publications throughout the history of the Journal of Range Management. This manuscript was improved after receiving comments on an earlier version from David Briske, David Engle, Larry Howery, John Malechek, and 2 anonymous reviewers.

Manuscript accepted 3 Aug. 1999.

\section{Resumen}

Durante un seminario entre estudiantes de nivel de posgrado, donde se seleccionaron las 5 artículos más importantes publicados por la Revista de Manejo de Pastizales durante los últimos cincuenta años (1948-1997), se cultivó una apreciación sobre el desarrollo de la disciplina de manejo y ciencia de los pastizales, logrando también una perspectiva histórica para enjuiciar a la Revista. Una revisión de libros de texto y artículos que describen el inicio y el uso de conteo de citas fueron muy útiles en el desarrollo de criterios para disernir la importancia de los artículos. El desacuerdo más grande entre los nueve participantes se dió por el uso conteo de citas como criterio. Dos estudiantes utilizaron el conteo como único criterio y 3 estudiantes se negarion a utilizarlo. Dieciocho artículos recibieron cuando menos un voto como los mejores 5 y 2 artículos sobre el monitoreo de sucesión vegetal fueron los más populares. El ejercicio reveló que el descontento con la Revista no es nada nuevo. Aunque actualmente, la Revista de Manejo de Pastizales cubre una gran variedad de temas, incluyendo artículos reduccionistas y de síntesis, algunos estudiantes manifestaron que abarcaba menos de los múltiples valores existentes en los pastizales que algunos textos recientes. Los estudiantes encontraron que la selección de artículos importantes expandía el entendimiento de la disciplina y su decisión de publicar en la Revista de Manejo de Pastizales.

pants to reflect on current concerns about the purpose and vitality of the JRM.

This paper describes the course format and selected papers, briefly critiques the selections, summarizes students' evaluations, and provides commentary about the JRM. The purpose of the paper is to stimulate similar reviews and dialogue about the lessons available in the first 50 years of the JRM.

\section{Course Form}

Discussions about the criteria for selecting important papers took place in the first 3 class sessions. The 9 subsequent sessions were devoted to student presentations of selection criteria and selected papers to build a candidate list of papers for final consideration. The final class session was used to vote for and discuss the top 5 selections for the complete 50 years of the $\mathrm{JRM}^{1}$ and to evaluate the course.

${ }^{1}$ Full-text copies of all articles in volumes $1-47$ of the JRM are now available on the Internet at http://jrm.library.arizona.edu 
Nine graduate students (5 Ph.D. and 4 M.S.) were enrolled in the seminar, and 1 to 3 faculty attended each weekly session. Two students had an undergraduate degree in rangeland science and management. Six of the students were enrolled in the rangeland science and management graduate program, and 1 student each in the wildlife and fisheries management, watershed management, and interdisciplinary renewable natural resources studies graduate programs. In general, student interests and previous course work were focused in vegetation ecology and management, wildlife ecology and management, and soil science. Expertise and interest in animal production and production economics was under-represented: only 7 of 9 students had at least 1 course in these subjects and no student had more than 2 courses in either subject.

\section{Selection Criteria}

Choosing selection criteria was the most difficult aspect of this exercise because there are no objective measures to identify a significant paper. The inherent subjectivity proved to be the basis for heated discussions that made a much greater impact in the students' appreciation for the development of the discipline than if they had followed a predetermined set of criteria.

Student-led discussions about selection criteria were aided by assigned readings of 10 textbooks (Heady 1975, Heady and Child 1994, Holechek et al. 1989, 1995, 1998, Sampson 1923, 1952, Stoddart and Smith 1943, 1955, Stoddart et al. 1975), a paper describing early milestones in the discipline (Chapline 1944), and a JRM paper illustrating the use of literature citation statistics to describe the evolution of scientific ideas (Joyce 1993). Textbooks were assigned because they reference the seminal works and synthesize the state-ofknowledge in a discipline. The textbooks were limited to those that had been revised at least once because revisions can reveal how new JRM papers influenced the authors to re-synthesize the discipline. For example, the Sampson (1923) and Stoddart and Smith (1943) texts provided pre-JRM baselines to judge the influence of early $J R M$ articles in their respective textbook revisions (Sampson 1952, Stoddart and Smith 1955); whereas the later texts and their revisions provided benchmarks for the importance of later JRM papers. Chapline (1944) grounded the students in the state-of-knowledge prior to the publication of the JRM. Joyce (1993) illustrated the use of the Science Citation Index (Institute for Scientific
Information 1955-1997) to measure the popularity of $J R M$ papers.

These references helped focus our discussions on the biases of citation counting versus its utility for estimating the importance of a paper. Students became aware of textbook and journal authors who frequently cited their own work, as well as the greater probability of paper citation in recent times because of the explosion of publishing scientists and periodicals. Furthermore, they discussed the problem of not knowing the context of the citation: was it used in a positive light or was it cited because it used flawed methods or made erroneous conclusions? In hindsight, the "invisible college" paper by Hart (1993) would have been an excellent addition to this list of readings because it exposed other sources of bias in the use of citation counting.

Each student developed their own selection criteria to rate the $J R M$ papers. In general, they applied 3 classes of criteria: citation counts, contribution to disciplinary paradigms, and generality. Citation counting used the 43 printings of the Science Citation Index (Institute for Scientific Information 1955-1997), textbooks, and the JRM. The contribution to disciplinary paradigms addressed management principles and underlying models of rangeland science and management. The criterion for paradigms of management principles favored papers that described how the sustainable use of rangelands is related to the intensity, season, frequency and kind/class of use (where uses include herbivore grazing, recreation, and vegetation manipulations such as fire and fertilization). The criterion for underlying models favored papers that proposed new models and methods to apply these models. For example, Dyksterhuis (1949) proposed a method to operationalize the Clementsian-based model of plant succession. The generality criterion favored papers that focused on synthesis and universality over papers that were specific to a few locations or species. For both the paradigm and generality criteria, students favored papers that had longstanding significance or resolved some controversy. Citation counting was the sole criterion used by 2 students, 3 students rejected citation counting and used only paradigms and generality, and 4 students used all the criteria.

\section{Selecting Top Papers}

Five or 6 consecutive volumes of the $J R M$ were assigned to each student to distribute a uniform time period and amount of work. All students were required to review the papers in all of the $J R M$ volumes to foster informed discussions. In each of 9 class sessions, a different student presented their criteria and the 5 most important papers in their 5 or 6 volumes. These presentations resulted in a list of 45 important papers published in the first 50 years of the $J R M$, and some intense discussions about the criteria used and the papers selected by students. Not all students were satisfied with their peers' selections, and therefore they added 5 "wildcard" papers to make a candidate list of 50 papers.

The most consistent debate concerned the reliance on citation counts as a surrogate for importance. Three students refused to use that criterion because counts reflected more on the popularity of a paper than its content or importance, but 2 students used counts as their only criterion. Debate about the importance of selections was common, for example Mueggler (1965) was challenged because it relied on the location of fecal material to infer animal distribution compared to direct measures of utilization used by Cook (1966). The third most common debate centered on the absence of papers from the lists, for example, economic analyses, grazing systems, and riparian management were among the under-represented topics.

\section{Selecting the Top 5 Papers}

Students took a week to apply their own criteria to select the 5 most important papers from the candidate list of 50 papers. These selections included a ranking of the papers and written statements justifying their selections. Each student's rankings was computed based on a score of 5 for their most important paper, and scores of 4, 3, 2, and 1 for their second, third, fourth and fifth most important papers, respectively. Individual scores were summed to create a class-wide score for each paper. With this method, the highest possible score would be 45 if all 9 students cast a top-paper vote for the same paper.

Eighteen papers received at least 1 vote, and papers by Dyksterhuis (1949), Westoby et al. (1989), Wilson and Tupper (1982), Bement (1969), and West (1993) were ranked as the 5 most important papers in the first 50 years of the JRM (Table 1). The students' ratings clearly elevated the papers by Dyksterhuis (1949) and Westoby et al. (1989) above the other 16 papers receiving votes, and there was little distinction among those 16 papers. 
Table 1. Rank and score of students' votes for papers considered to be part of the 5 most important published in the Journal of Range Management volumes 1-50, 1948-1997.

\begin{tabular}{|c|c|c|}
\hline 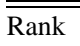 & Score & Citation in the Journal of Range Management \\
\hline 1 & 44 & Dyksterhuis, E.J. 1949. Condition and management of rangeland based on quantitative ecology. 2:104-115. \\
\hline 2 & 35 & Westoby, M., B. Walker, and I. Noy-Meir. 1989. Opportunistic management for rangelands not at equilibrium. 42:266-274. \\
\hline 4 tie & 7 & Bement, R.E. 1969. A stocking-rate guide for beef production on blue grama range. 22:83-86. \\
\hline 4 tie & 7 & West, N.E. 1993. Biodiversity of rangelands. 46:2-13. \\
\hline 6 & 6 & Provenza, F.D. 1992. Mechanisms of learning in diet selection with reference to phytotoxicosis in herbivores. 45:36-45. \\
\hline 7 tie & 4 & Friedel, M.H. 1991. Range condition assessment and the concept of thresholds: a viewpoint. 44:422-426. \\
\hline 9 tie & 3 & Heady, H.F. and D.T. Torrell. 1959. Forage preference exhibited by sheep with esophageal fistulas. 12:28-34. \\
\hline 9 tie & 3 & $\begin{array}{l}\text { Reardon, P.O. and L.B. Merrill. 1976. Vegetation responses under various grazing management systems in the Edwards Plateau of } \\
\text { Texas. 29:195-198 }\end{array}$ \\
\hline 9 tie & 3 & Hanley, T.A. 1982. The nutritional basis for food selection by ungulates. 5:146-151. \\
\hline 15 tie & 1 & Roach, M.E. 1950. Estimating perennial grass utilization on semidesert cattle ranges by percentage of ungrazed plants. 3:182-185. \\
\hline 15 tie & 1 & Cook, C.W. 1954. Common use of summer range by sheep and cattle. 7:10-13. \\
\hline 15 tie & 1 & $\begin{array}{l}\text { Van Dyne, G.M. 1966. Application and interpretation of multiple linear regression and linear programming in renewable resources } \\
\text { analysis. 19:356-362. }\end{array}$ \\
\hline 15 tie & 1 & $\begin{array}{l}\text { Bailey, D.W., J.E. Gross, E.A. Laca, L.R. Rittenhouse, M.B. Coughenour, D.M. Smith and P.L. Sims. 1996. Mechanisms that } \\
\text { result in large herbivore grazing distribution patterns. 49:386-400. }\end{array}$ \\
\hline
\end{tabular}

${ }^{\mathrm{T}}$ Score is the sum of 9 students ranking their top 5 papers from $5=$ most important to $1=$ fifth most important.

\section{Critique of Top Papers}

This critique is brief for 3 reasons. First, to maintain the focus on the selection process rather than the selections. Second, the small class size, narrow specialties, and southwestern United States orientation created important biases. Third, the method of selecting 5 candidate papers from 5 or 6 volumes assumed a regular distribution of important papers.

The top 2 papers, Dyksterhuis (1949) and Westoby et al. (1989) focused on important underlying models of rangeland plant succession and operational tools to implement the models for monitoring efforts. Two student comments illustrate justification for these rankings. About Dyksterhuis, one student wrote:

"...spelled out the principles of Clementsian succession and their application to rangeland condition assessment and grazing management. These principles endured for more than four decades and were widely used on rangelands across the world."

About Westoby et al., one student wrote:

"Theories proposing multiple successional pathways and alternative stable states were not new... and the shortcomings of the traditional successional model were well known, but the appearance of [this paper's] state-andtransition model heralded serious consideration [of these ideas] by the range profession. The state-and-transition model and its variations promise to have enduring and widespread impacts on the science of range management..."

The time from the proposal of a model to its application for management may be a measure of disciplinary progress. Dyksterhuis (1949) provided the operational tools to implement Clementsian ideas (Clements 1916) that were first articulated and modified for rangeland management 30 years earlier in Sampson (1919). Whereas, in only 8 years, the revision of the National Range and Pasture Handbook (Natural Resource Conservation Service 1997) began applying the concepts of Westoby et al. (1989) to organize empirical information about rangeland plant succession that built on multiple stable state theory (May 1977).

\section{Student and Faculty Evaluations}

Each student prepared a written evaluation of this exercise during the week that they were selecting their top 5 papers from the list of 50 papers. The evaluations were largely positive, except for complaints about the large amount of reading. The students identified 3 types of benefits: acculturation with the rangeland science and management discipline, exposure to relevant information, and appreciation for the evolution of the discipline. About acculturation, 1 student wrote "I appreciated the small treasures of the time period such as photos of old faculty members, notorious quotes, and thought provoking book reviews". The benefit of exposure to relevant information is apparent in this comment: "Each student was able to identify even the earliest papers published relevant to their research ..." Expressions of increased appreciation for the evolution of the discipline included statements like "This exercise provided exposure to the historical development of the most fundamental ideas", “... presented me with tools and opportunities to develop my own philosophies of the range management profession", and "I was surprised to discover that many if not most of today's issues already existed in 1948".

One student's summary of this exercise was particularly gratifying because it suggests that the course achieved its goals of cultivating an appreciation of past accomplishments. 
"The value of this exercise is not in the final list of articles; neither at the individual student level, nor at the class level. It is in the journey through the history of the science of range management, the understanding of that history, and increasing understanding of the driving forces and interests of other individuals, including your traveling partners."

This was one of the most rewarding teaching experiences of my career because the students learned a great deal about the $J R M$ and the discipline, they expressed a sincere interest in doing the hard work to complete the assignment, and they took seriously their commitment to express opinions and respectfully engage in discussions that included important differences of opinion. Furthermore, it was a very efficient review of trends in the discipline. For example, they observed that early efforts at shrub management focused on elimination using herbicides (e.g. Hull and Vaughn 1951), later publications documented the shorter than expected lifespan of shrub control treatments (e.g. Johnson 1969), a later publication described seemingly antithetical efforts to establish shrubs (Giunta et al. 1975), and more recently a publication presented a more integrated approach to shrub management (Scifres 1987).

The entire experience resonates with Art Smith's (Smith 1952) sage commentary that the goal of teaching should be more about ideas and less about facts: 'When a student has been stimulated to thinking about a particular field concerned, he can later acquire details, and moreover, he may uncover some new facts or provide some new tools in the process."

\section{Future of the Journal}

Completing this exercise gave all participants the license to contribute to the discussion about the status and relevance of the JRM. One student suggested that the $J R M$

“...has always been and remains a publication devoted to livestock production ... and it needs to take a broader view in order to become a more relevant force in the future [and] this transition seems to be underway in the modern textbooks which reflect the increasing importance of other uses of rangelands."

There is a long history of criticism about the JRM content in its first 50 years (e.g.
Schultz 1958). Recent, criticism includes devotion to trivia at the expense of larger socio-ecologic issues (Starrs 1998), a decline in scientific impact, credibility, and relevancy (Fuhlendorf et al. 1999), and a lack of broader syntheses relative to emphasis on narrower primary research (Schultz and Zamudio 1998).

I join those who want the $J R M$ to be a more significant journal in its content and be recognized beyond the discipline. However, my assessment of the JRM is different from other commentators. First, the $J R M$ is replete with detailed information found in many specific studies. Although this may appear to be trivial, detailed information definitely is required to build a disciplinary foundation for predictions about resource responses to management. Second, there has been an increasing number of $J R M$ articles in the past 5-10 years that address the difficult social-ecological issues of rangeland policy (e.g. Loomis et al. 1989, Huntsinger and Fortmann 1990, Collins and Obermiller 1992, Rowan et al. 1994, Brunson and Steel 1996, Huntsinger and Hopkinson 1996, Mitchell et al. 1996, Moote and McClaran 1997, Raymond 1997) and I hope that trend will continue. Third, we should strive to attract a broader audience through the publication of both reductionist primary research as well as papers that synthesize and assess the merit, application and future challenges of a specific topic. Apparently, the students recognized that these are not mutually exclusive pursuits because 2 of the 9 invited papers in the current $J R M$-sponsored synthesis series (started in 1987) were included in their top 18 papers (i.e., West 1993, Bailey et al. 1996; Table 1). Finally, we must recognize that the future of the $J R M$ rests primarily with those who publish research results about rangeland resources and their use. Therefore, it is incumbent upon us to submit our best work to the $J R M$ because it can only be as important, credible, and broadly read as the quality of the manuscripts we submit for publication.

\section{Benefits and Challenges}

The lasting value of this review was in the students' development of a more complete understanding of the discipline of rangeland science and management. As a result, their work is more likely to build on the merits of past work, avoid repeating past mistakes, and be submitted for publication in the JRM. The students' list of important papers will certainly be criticized for missing important works and over-valuing others because the student group was small and narrow in expertise. Ideally, by sharing the students' experience, others will be challenged to complete a similar review of the first 50 years of the $J R M$ to recognize seminal works, cultivate a deeper understanding of the discipline, and stimulate submission of outstanding work for publication in the JRM.

\section{Literature Cited}

Bailey, D.W., J.E. Gross, E.A. Laca, L.R. Rittenhouse, M.B. Coughenour, D.M. Smith, and P.L. Sims. 1996. Mechanisms that result in large herbivore grazing distribution patterns. J. Range Manage. 49:386-400.

Bement, R.E. 1969. A stocking-rate guide for beef production on blue grama range. J. Range Manage. 22:83-86.

Brunson, M.W. and B.S. Steel. 1996. Sources of variation in attitudes about federal rangeland management. J. Range Manage. 49:69-75.

Campbell, R.S. 1948. Milestones in range management. J. Range Manage. 1:4-8.

Chapline, W.R. 1944. The history of western range research. Ag. History 18:127-143.

Clements, F.E. 1916. Plant Succession, an Analysis of the Development of Vegetation. Carnegie Institute of Washington, Washington, D.C.

Collins, A.R. and F.H. Obermiller. 1992. Interdependence between public and private forage markets. J. Range Manage. 45:183-188.

Cook, C.W. 1954. Common use of summer range by sheep and cattle. J. Range Manage. 7:10-13.

Cook, C.W. 1966. Factors affecting utilization of mountain rangelands of the western United States. J. Range Manage. 19:200-204.

Dyksterhuis, E.J. 1949. Condition and management of rangeland based on quantitative ecology. J. Range Manage. 2:104-115.

Friedel, M.H. 1991. Range condition assessment and the concept of thresholds: a viewpoint. J. Range Manage. 44:422-426.

Fuhlendorf, S.D., C.S. Boyd, and D.M Engle. 1999. SRM philosophy: science or advocacy? Rangelands 21(1):20-23.

Giunta, B.C., D.R. Christensen, and S.B. Monsen. 1975. Interseeding shrubs in cheatgrass with a browse seeder-scalper. J. Range Manage. 28:398-402.

Hanley, T.A. 1982. The nutritional basis for food selection by ungulates. J. Range Manage. 35:146-151.

Hart, R.H. 1993. Invisible colleges and citation clusters in stocking rate research. J. Range Manage. 46:378-382.

Heady, H.F. 1975. Rangeland Management. McGraw-Hill, New York, N.Y. 
Heady, H.F. and R.D. Child. 1994. Rangeland Ecology and Management. Westview Press, Boulder, Colo.

Heady, H.F. and D.T. Torrell. 1959. Forage preference exhibited by sheep with esophageal fistulas. J. Range Manage. 12:28-34.

Holechek, J.L., R.D. Pieper, and C.H. Herbel. 1989. Range Management: Principles and Practices. Prentice-Hall, Upper Saddle River, N.J.

Holechek, J.L., R.D. Pieper, and C.H. Herbel. 1995. Range Management: Principles and Practices. $2^{\text {nd }}$ ed. Prentice-Hall, Upper Saddle River, N.J.

Holechek, J.L., R.D. Pieper, and C.H. Herbel. 1998. Range Management: Principles and Practices. $3^{\text {rd }}$ ed. Prentice-Hall, Upper Saddle River, N.J.

Hull, A.C. Jr. and W.T. Vaughn. 1951. Controlling sagebrush with 2,4-D and other chemicals. J. Range Manage. 4:158-165.

Huntsinger, L. and L.P. Fortmann. 1990. California's privately owned oak woodlands: owners, use, and management. J. Range Manage. 42:147-152.

Huntsinger, L. and P. Hopkinson. 1996. Sustaining rangeland landscapes. J. Range Manage. 49:167-173.

Institute for Scientific Information. 1955-1997. Science Citation Index. Institute for Scientific Information, Philadelphia, Penn.

Johnson, W.M. 1969. Life expectancy of a sagebrush control in Wyoming. J. Range Manage. 22:177-182.

Joyce, L.A. 1993. The life cycle of the range condition concept. J. Range Manage. 46:132-138.

Lockwood, J.A. and D.R. Lockwood. 1993. Catastrophe theory: a unified paradigm for rangeland ecosystem dynamics. J. Range Manage. 46:282-287.

Loomis, J., D. Donnelly, and C. Sorg-Swanson. 1989. Comparing the economic value of forage on public lands for wildlife and livestock. J. Range Manage. 42:134-138
May, R.M. 1977. Thresholds and breakpoints in ecosystems with a multiplicity of stable states. Nature 269:471-477.

Mitchell, J.E., G.N. Wallace, and M.D. Wells. 1996. Visitor perceptions about cattle grazing on National Forest land. J. Range Manage. 49:81-86.

Moote, M.A. and M.P. McClaran. 1997. Implications of participatory democracy in public land planning. J. Range Manage. 50:473-481.

Mueggler, W.F. 1965. Cattle distribution on steep slopes. J. Range Manage. 18:255-257.

Natural Resource Conservation Service. 1997. National Range and Pasture Handbook. U.S. Department of Agriculture.

Provenza, F.D. 1992. Mechanisms of learning in diet selection with reference to phytotoxicosis in herbivores. J. Range Manage. 45:36-45.

Raymond, L. 1997. Are grazing rights on public lands a form of private property? J. Range Manage. 49:431-438.

Reardon, P.O. and L.B. Merrill. 1976. Vegetation responses under various grazing management systems in the Edwards Plateau of Texas. J. Range Manage. 29:195-198.

Roach, M.E. 1950. Estimating perennial grass utilization on semidesert cattle ranges by percentage of ungrazed plants. J. Range Manage. 3:182-185

Rowan, R.C., H.W. Ladewig, and L.D. White. 1994. Perceptions vs. recommendations: a rangeland decision-making dilemma. J. Range Manage. 47:344-348.

Sampson, A.W. 1919. Plant succession in relation to range management. USDA Bull. 791.

Sampson, A.W. 1923. Range and Pasture Management. John Wiley and Sons, New York, N.Y.

Sampson, A.W. 1952. Range Management: Practices and Principles. John Wiley and Sons, New York, N.Y

Schultz, A.M. 1958. I'm not satisfied with the Journal. J. Range Manage. 11:107-108 Letter to the Editor.
Schultz, B.W. and D.C. Zamudio. 1998. Bridging the gap between rangeland management and rangeland research: the need for regular inclusion of synthetic review articles in the Journal of Range Management. Rangelands 20(5):30-35.

Scifres, C.J. 1987. Decision-analysis approach to brush management planning: ramifications for integrated range resources management. J. Range Manage. 40:482-490.

Smith, A.D. 1952. What should the goal of range education be? J. Range Manage. 5:304-305

Starrs, P. 1998. Let the cowboy ride: cattle ranching in the American west. Johns Hopkins University Press, Baltimore, Md.

Stoddart, L.A. and A.D. Smith. 1943. Range Management. McGraw-Hill, New York, N.Y.

Stoddart, L.A. and A.D. Smith. 1955. Range Management. $2^{\text {nd }}$ ed. McGraw-Hill, New York, N.Y

Stoddart, L.A., A.D. Smith, and T.W. Box. 1975. Range Management. $3^{\text {rd }}$ ed. McGraw-Hill, New York, N.Y.

Task Group on Unity in Concepts and Terminology. 1995. New concepts for assessment of rangeland condition. J. Range Manage. 48:271-282.

Van Dyne, G.M. 1966. Application and interpretation of multiple linear regression and linear programming in renewable resources analysis. J. Range Manage. 19:356-362.

West, N.E. 1993. Biodiversity of rangelands. J. Range Manage. 46:2-13.

Westoby, M., B. Walker, and I. Noy-Meir. 1989. Opportunistic management for rangelands not at equilibrium. J. Range Manage. 42:266-274.

Wilson, A.D. and G.J. Tupper. 1982. Concepts and factors applicable to the measurement of range condition. J. Range Manage. 35:684-689. 